\title{
Effect of Employee Equity Satisfaction on Service Transactions in the Tourism Sector in Kerinci
}

\author{
Dasman Lanin ${ }^{1}$, Syamsir $^{2}$, Boni Saputra ${ }^{3}$ \\ dasman@fis.unp.ac.id ${ }^{1}$, syamsir@fis.unp.ac.id ${ }^{2}$, bonisaputra@ fis.unp.ac.id ${ }^{3}$, \\ Department of Public Administration, Universitas Negeri Padang, Padang, Indonesia ${ }^{1,2,3}$
}

\begin{abstract}
This study aims to analyze employee equity satisfaction with service transactions (delivery, professionalism, information, timeliness, staff attitude) in the tourism sector in Kerinci. How does employee equity satisfaction with service transactions (delivery, professionalism, information, timeliness, staff attitude) in the tourism sector in Kerinci? A quantitative approach has been chosen to test this objective. The population in this study were all Kerinci tourism employees. Data were collected from 39 respondents who were taken by using a stratified sampling technique. Validated and reliable questionnaires were used in this study, then analyzed by regression. The results found are that employee equity satisfaction has a significant positive effect on service transactions. The significance is 0.000 , and the contribution is 0.771 .
\end{abstract}

Keywords: Equity Satisfaction, Service Transaction

\section{Introduction}

The review's internal customer satisfaction theory appreciated in this research is Equity Theory, although there are many other satisfaction theories such as Attribution Theory, Disconfirmation Theory/Model, job satisfaction, and other theories. Moreover Menpan RB RI used confirmation theory. The implementation of the model found [1] in different sectors in West Sumatra shows a significant effect of employee equity satisfaction on service transactions. Now, want to see and prove or test whether the implementation among the Kerinci ethnic group is the same with sectors in West Sumatra? This means that if applied or researched on a specific ethnicity, such as among the Kerinaci ethnic group, it will also show how. Therefore, this study focuses on how the Effect of Employee Equity Satisfaction on Service Transactions in the Tourism Sector in Kerinci ethnic ethnicity?

Based on a literature review from various experts, some mention several trem for service transactions. Some call the determinants of service for community satisfaction, some call them variables that affect community satisfaction, some provide them with predictors that can predict the satisfaction of their citizens, and some are named service transactions. Thomson and Mori (2014) [2] suggest that citizen satisfaction with public services in the UK is influenced by (1) delivery, (2) timeliness, (3) information accuracy, (4) professionalism, and (5) staff attitude can be predictors of citizen satisfaction. Mintzberg's as researched [3, 4], states that influencing manager roles toward increasing public services on local government. Then, as for the external role construct of manager used theory and construct of citizen satisfaction used Expectancy 
Disconfirmation the Model Citizen Satisfaction Local Government of Ryzin \& Gregg, its result showed significant correlation [5]. In particular, Dasman Lanin reports that influence of internal organizational politics, both as independent variables and analyzed per indicator, is proven to have a significant effect on community satisfaction in the fields of education, health and community welfare.[4].

If the review literature above is concluded, there are five intermediate variables that affect satisfaction, which connect employees and society. Therefore, we give the name Service Transaction, which includes: delivery, timeliness, information, professionalism, staff attitude, and internal political organization. Moreover delivery has characteristics: the final result, how to keep promises, how to handle problems, and commit to the customer. Timeliness characterized the waiting period, length of completion, frequency of contact, and explanation length. Information that has characteristics: accuracy, comprehensiveness, urgency, and freshness. The professionalism is competent staff, staff who behave reasonably, knowledgeable, and well trained. Staff Attitude, dealing with friendly \& polite, sympathetic, honest, sincere \& impartial, fair \& equal relationships, avoiding bad morals, adaptive \& strategic thinking, moralist \& virtuous. Political internal organization, in the form of goals for certain people, favoritism, influenced by political pressure, clique competition, deviations from organizational goals, and unclear division of tasks.

Theoretically, the theory of satisfaction is quite a lot of which are; (1) attribution theory, (2) contrast theory, (3) assimilation theory, (4) contrast-assimilation theory, (5) disconfirmation theory, (6) confirmation theory, and (7) equity theory. It turns out that one thing that can measure internal customers or employees is equity theory [6]. So this theory is used as the foundation of this research.

According to [7] every democratic government, equity satisfaction is a fundamental need that met. According to [8], in the framework of creating satisfaction, there is an equity theory that can used, and there is also an equal and fair, said [9] The law of equity theory assumes that each party related to service transactions must be the same [10]. In the original, "equity theory focuses on individuals' perception of how fairly they are being treated compared to others and the behavioral implications of their perceptions" [11]. Then [11] explains in more detail that "Individuals engage in the process of evaluating their social relationships much like they would evaluate economic transactions in the marketplace. Social relationships are an exchange process in which individuals make contributions or investments and expect certain outcomes in return"..."people do not assess the equity of an exchange in a vacuum. Instead, they compare their situation with others' to determine the relative balance. People determine whether an exchange is satisfactory by comparing what happens to themselves what happens to others".

Furthermore, [9] said that only a few individuals, favoritism; affected by political pressures; hence customer satisfaction decreased significantly. Unlike when bureaucrats just bureaucrat [8], equity satisfaction increases with relevance, even when public service shows impartial and honest and equal and fair customer satisfaction increases in government [9].

Previous Research: In 2018 and 2019, Dasman Lanin has examined the effect of equity satisfaction on satisfaction in the RSUD [12] and its effect on the three public sectors in immigration, labor, and industry in population and civil registration [1]. Then, research [13], [14] found; local government service models for customer satisfaction (internal/employee and external/community) based on [14]; Reconstruction of satisfactory services [15]; local government service models [3], [16]-[20]; found six variables that affect satisfaction [21]-[24]; satisfaction determined by delivery, timeliness, information, staff attitudes, professionalism and internal politics of the organization [5], [17], [21]; Theoretically, organization-internal politics factors can be used as a predictor to determine citizen satisfaction of local government service 
[4]; Professionalism and employee attitudes have a positive correlation with citizen satisfaction [16]; Attitude of officials affects citizen satisfaction (2010a); Citizen satisfaction with city government is in negative disconfirmation [4].

\section{Methodology}

This research method uses quantitative methods with correlation. The research variables and indicators are; The independent variable is the Internal Customer (Employee) Equity Satisfaction with an indicator that customers assess the ratio of the results they get and the input they compared to the results and input of others in the same service transaction. While the independent variable is Service Transaction, which consists of; (1) delivery with indicators; the result, how to keep promises, commit to the customer, how to handle problems. (2) Time with indicators; waiting period, duration of completion, frequency of contact, length of explanation (3) Information with indicators of accuracy, comprehensiveness, urgency, freshness. (4) Professionalism with indicators; competent staff, fair-behaved, knowledgeable and well-trained staff. (5) Staff Attitude with indicators; friendly \& polite, sympathetic, honest, sincere \& impartial, fair \& same relationship, avoiding bad morals, adaptive \& strategic thinking, moralist $\&$ virtuous. All of these indicators have made a valid and reliable questionnaire. Then data were collected from 39 respondents who were taken by using a stratified sampling technique and analyzed with product-moment, and regression.

\section{Finding And Discussion}

Service transaction is the provider's interaction with the public (external) or employees (internal). This service transaction involves delivery, timeliness, information, professionalism, and staff attitude. Service transactions can be affected by several variables, including equity satisfaction. How the effect of equity satisfaction on each of these service transactions can stated in the following research analysis.

\subsection{Equity Satisfaction and Delivery}

The correlation of equity satisfaction with delivery can seen in the table below.

Table 1. Correlation of Equity Satisfaction toward Delivery

\begin{tabular}{lrrrrr}
\hline Model & R & R Square & Adjusted R Square & $\begin{array}{c}\text { Std. The error of } \\
\text { the Estimate }\end{array}$ & Durbin-Watson \\
\hline 1 &, $451^{\text {a }}$ &, 203 &, 182 &, 971 & 2,090 \\
\hline a. Predictors: (Constant), Equity & & & & \\
b. Dependent Variable: Delivery
\end{tabular}

Based on the table above, it can seen that the correlation between equity satisfaction and delivery is 0.451 and the contribution is 0.203 , while the Adjusted R Square in this research location or Kerinci tourism is 0.182 . So it can be said that these two variables have a close relationship. How significant the strength of the relationship is can seen in the results of the following regression analysis. 
Table 2. Significance Level Between Equity Satisfaction and Delivery

\begin{tabular}{llrrrrr}
\hline Model & & Sum of Squares & df & Mean Square & F & Sig. \\
\hline 1 & Regression & 8,885 & 1 & 8,885 & 9,431 &, $004^{\mathrm{b}}$ \\
& Residual & 34,859 & 37 &, 942 & & \\
& Total & 43,744 & 38 & & & \\
\hline
\end{tabular}

a. Dependent Variable: Delivery

b. Predictors: (Constant), Equity

Based on the table above, it shows that delivery has been affected by employee equity satisfaction with a confidence level of more than 0.99 or with a significance level of 0.004 . So it can be ascertained that employee satisfaction equity can used as a predictor of criterion delivery with confidence.

\subsection{Equity satisfaction and timeliness}

The correlation of equity satisfaction with the timeliness variable can seen in the table below.

Table 3. Correlation of Equity Satisfaction Toward Timeliness

\begin{tabular}{|c|c|c|c|c|c|}
\hline Model & $\mathrm{R}$ & R Square & Adjusted R Square & $\begin{array}{l}\text { Std. An error of } \\
\text { the Estimate }\end{array}$ & Durbin-Watson \\
\hline 1 &, $440^{\mathrm{a}}$ & , 193 &, 171 & ,766 & 2,051 \\
\hline
\end{tabular}

Based on the table above, it can seen that the correlation between employee equity satisfaction and timeliness is 0.440 and its contribution is 0.193 , while the Adjusted R Square or its contribution at the location of this study or in the Kerinci tourism office is 0.171 . So it can be said that these two variables have a close relationship. How significant the strength of the relationship is can seen from the results of the following regression analysis.

Table 4. Significance Level Between Equity Satisfaction and Timeliness

\begin{tabular}{llrrrrr}
\hline Model & & Sum of Squares & df & Mean Square & F & \multicolumn{1}{c}{ Sig. } \\
\hline 1 & Regression & 5,203 & 1 & 5,203 & 8,862 &, $005^{\text {b }}$ \\
& Residual & 21,721 & 37 &, 587 & & \\
& Total & 26,923 & 38 & & & \\
\hline
\end{tabular}

a. Dependent Variable: Timeliness

b. Predictors: (Constant), Equity

Based on the table above, it shows or has proven that timeliness has been affected by employee equity satisfaction with a confidence level of more than 0.99 or with a significance level of up to 0.005 . So it can be ascertained that employee satisfaction equity can used as a predictor of criterion timeliness with confidence. 


\subsection{Equity satisfaction and Information}

The relationship of equity employee satisfaction with information can seen in the table below.

Table 5. Correlation of Equity Satisfaction toward Information

\begin{tabular}{lrrrrr}
\hline Model & R & R Square & Adjusted R Square & $\begin{array}{c}\text { Std. An error of } \\
\text { the Estimate }\end{array}$ & Durbin-Watson \\
\hline 1 &, $395^{\text {a }}$ &, 156 &, 133 &, 813 & 1,966 \\
\hline $\begin{array}{l}\text { a. Predictors: (Constant), Equity } \\
\text { b. Dependent Variable: Information }\end{array}$
\end{tabular}

Based on the table above, it can seen that the correlation between employee equity satisfaction and information is 0.395 , and its contribution is 0.156 , while the Adjusted R Square or its contribution at the location of this study or in the Kerinci tourism office is 0.133 . So it can be said that these two variables have a close relationship. How significant the strength of the relationship is can seen from the results of the following regression analysis.

Table 6. Significance level between Equity Satisfaction and Information

\begin{tabular}{llrrrrr}
\hline Model & & Sum of Squares & Df & Mean Square & F & Sig. \\
\hline 1 & Regression & 4,517 & 1 & 4,517 & 6,834 &, $013^{\mathrm{b}}$ \\
& Residual & 24,457 & 37 &, 661 & \\
& Total & 28,974 & 38 & & \\
\hline
\end{tabular}

a. Dependent Variable: Information

b. Predictors: (Constant), Equity

Based on the table above, it shows or has proven that information has been affected by employee equity satisfaction with a confidence level of more than 0.99 or with a significance level of 0.013 . So it can be ascertained that employee satisfaction equity can be used as a predictor of criterion timeliness with confidence.

\subsection{Equity satisfaction and Professionalism}

The effect of employee equity satisfaction on professionalism can seen in the table below.

Table 7. Correlation of Equity Satisfaction toward Professionalism

\begin{tabular}{|c|c|c|c|c|c|}
\hline Model & $\mathrm{R}$ & R Square & Adjusted R Square & $\begin{array}{l}\text { Std. An error of } \\
\text { the Estimate }\end{array}$ & Durbin-Watson \\
\hline 1 &, $616^{\mathrm{a}}$ & ,379 &, 362 & ,728 & 2,185 \\
\hline
\end{tabular}

Based on the table above, it can seen that the correlation between employee equity satisfaction and professionalism is 0.616 , and its contribution is 0.379 , while the Adjusted $\mathrm{R}$ 
Square or its contribution at the location of this study or in the Kerinci tourism office is 0.362 . So it can be said that these two variables have a close relationship. How significant the strength of the relationship is can seen from the results of the following regression analysis.

Table 8. Significance level between Equity Satisfaction and Professionalism

\begin{tabular}{lllllll}
\hline Model & & Sum of Squares & Df & Mean Square & F & Sig. \\
\hline 1 & Regression & 11,973 & 1 & 11,973 & 22,584 &, $000^{\mathrm{b}}$ \\
& Residual & 19,616 & 37 &, 530 & & \\
& Total & 31,590 & 38 & & & \\
\hline
\end{tabular}

a. Dependent Variable: Professionalism

b. Predictors: (Constant), Equity

Based on the table above, it shows or has proven that professionalism has been affected by the equity satisfaction of employees with a confidence level of more than 0.99 or with a significance level of up to 0.000 . So it can be ascertained that employee satisfaction equity can used as a predictor of criterion professionalism with confidence.

\subsection{Equity satisfaction and Staff Attitude}

The correlation of employee satisfaction with staff attitude equity as a service transaction variable can seen in the table below.

Table 9. Correlation of Equity Satisfaction toward Staff Attitude

\begin{tabular}{lrrrrr}
\hline Model & R & R Square & Adjusted R Square & $\begin{array}{c}\text { Std. An error of } \\
\text { the Estimate }\end{array}$ & Durbin-Watson \\
\hline 1 &, $662^{\mathrm{a}}$ &, 439 &, 424 &, 650 & 1,868 \\
\hline $\begin{array}{l}\text { a. Predictors: (Constant), Equity } \\
\text { b. Dependent Variable: staff attitude }\end{array}$ & & & & \\
\end{tabular}

Based on the table above, it can seen that the correlation between employee equity satisfaction and staff attitude is 0.662 , and the contribution is 0.439 , while the Adjusted R Square or its contribution at the location of this study or in the Kerinci tourism office is 0.424 . So it can be said that these two variables have a close relationship. How strength of the relationship is can seen from the results of the following regression analysis.

Table 10. Significance level between Equity Satisfaction and Staff Attitude

\begin{tabular}{llrrrrr}
\hline Model & & Sum of Squares & \multicolumn{1}{c}{ Df } & Mean Square & F & \multicolumn{1}{c}{ Sig. } \\
\hline 1 & Regression & 12,244 & 1 & 12,244 & 28,941 &, $000^{\mathrm{b}}$ \\
& Residual & 15,654 & 37 &, 423 & & \\
& Total & 27,897 & 38 & & & \\
\hline
\end{tabular}

a. Dependent Variable: staff attitude

b. Predictors: (Constant), Equity

Based on the table above, it shows or has proven that professionalism has been affected by the equity satisfaction of employees with a confidence level of more than 0.99 or with a 
significance level of up to 0.000 . So it can be ascertained that employee satisfaction equity can used as a predictor of the criterion of staff attitude with confidence.

\subsection{The employee satisfaction equity with all service transactions}

The correlation of employee satisfaction equity with all service transactions (delivery, timeliness, information, professionalism, staff attitude) can seen in the table below.

Table 11. Correlation of Equity Satisfaction toward Service Transactions

\begin{tabular}{|c|c|c|c|c|c|}
\hline Model & $\mathrm{R}$ & R Square & Adjusted R Square & $\begin{array}{l}\text { Std. An error of } \\
\text { the Estimate }\end{array}$ & Durbin-Watson \\
\hline 1 &, $771^{\mathrm{a}}$ & ,595 & ,584 & 1,990 & 1,760 \\
\hline
\end{tabular}

Based on the table above, it can be seen that the correlation between employee equity satisfaction with all Service Transactions is 0.771 and its contribution is 0.595 , while the Adjusted R Square or its contribution at this research location or in the Kerinci tourism office is 0.584 . So it can be said that these two variables have a close relationship. How strength of the relationship is can seen from the results of the following regression analysis.

Table 12. Significance level between Equity Satisfaction and Service Transaction

\begin{tabular}{llrrrrr}
\hline Model & & Sum of Squares & df & Mean Square & F & Sig. \\
\hline 1 & Regression & 215,221 & 1 & 215,221 & 54,367 &, $000^{\mathrm{b}}$ \\
& Residual & 146,472 & 37 & 3,959 & & \\
& Total & 361,692 & 38 & & & \\
\hline
\end{tabular}

a. Dependent Variable: All Service Transaction

b. Predictors: (Constant), Equity

\subsection{Discussion}

The table above shows or has proven that service transactions have been affected by employee equity satisfaction with a confidence level of more than 0.99 or with a significance level of up to 0.000 . So it can be ascertained that employee satisfaction equity can be used as a predictor of Service Transaction criterion with confidence. This also been proven in previous research in RSUD, Immigration, Labor and Industry as well as Population and Civil Registration that supported in the relevant research above [1], [23]. Furthermore, equity satisfaction increases with relevance, even when public service shows impartial and honest and equal and fair customer satisfaction increases in government [9].

Many of the above research results are supported by other research, as the results of researchers O'Kelly (2009) and Vigado-Gadot (2008) as stated in the previous theory. then Dasman Lanin (2018 and 2019) also supports the results of this study as presented in this Previous Research 


\section{Conclusion}

Based on the research results above which are supported by previous research data, this study can concluded that employee equity satisfaction has a significant effect on all service transactions, either together with its contribution of 0.771 or partially or respectively. This research note recommends researching various ethnic groups in Indonesia or ethnic groups outside Indonesia.

Acknowledgment. This article is part of the research scheme for Masters (S2) in Public Administration funded by LP2M UNP in 2020, and for that, we, the research team, would like to thank LP2M and the Rector of UNP for providing this funding facility.

\section{References:}

[1] S. Astuti, Wenny, Lanin, Dasman, "The Effect of Employee Satisfaction on Service Quality Through Delivery and Professionalism in Labor and Industrial Agency of Padang City", in Advances in Social Science, Education and Humanities Research [Internet]. Atlantis Press, 2019, vol 458,. Available at: http://creativecommons.org/license/by-nc/4.0/.

[2] W. \& M. Thomson, "Customer Satisfaction With Key Public Services", www.cabinetoffice.gov.uk/opsr., 2014. www.cabinetoffice.gov.uk/opsr.

[3] Dasman Lanin, "Influencing Manager Roles Toward Increasing Public Service on Local Government", 2008.

[4] Dasman Lanin, "Kepuasan Warga Terhadap Perkhidmatan Kerajaan Tempatan Padangpanjang", University Utara Malaysia, 2010.

[5] Dasman Lanin, "Citizen Satisfaction With local Government. International Conference of Public Organization", 2012.

[6] G. Tjipto, F, Chandra, Service, Quality \& Satisfaction. Jakarta: Andi Offset, 2010.

[7] IDEA, "International Institute of Democracy and Electoral Assistance.", https://www.idea.int/publications/categories/report, https://www.idea.int/publications/categories/report.

[8] J. O'Kelly, C\& Dubnick, M, Taking Tough Choices Seriously: Public Administration and Individua Moral Agency, vol 16. Oxford: University Press, 2009.

[9] E. Vigado-Gadot, "Citizen's Perceptions of Politics and Ethics in Public Administration: A Five-Year National Study of Their Relationship to Satisfaction with Services, Trustin Governance, and Voice Orientations", in JPART, vol 17, Oxford, 2008.

[10] S. D. M. And S. Heni, "Restructuring the Corruption Law Enforcement Model that Optimizes Corporation as Corruption Subject of Criminal Act", 2018, [Online]. Available at: http://repository.lppm.unila.ac.id/10696/2/Proceeding i-coffees 2018_final edition.pdf.

[11] L. Daft, R, Understanding the Theory and Design of Organizations with CourseMate. New York: Amazon, 2014.

[12] Dasman Lanin, "The Equity Satisfaction Model and Total Quality Management in Public Service of Local Government", 2018.

[13] L. Dasman, "Pengaruh Peranan Manajer Terhadap Kepuasan Warga Dengan Pelayanan Pemerintahan Daerah", J. Ilmu Sos. Polit., 2007.

[14] H. Dasman, Lanin, Nailuredha, "The Public Service Quality Model: Its Determinant (an Innovation in the perspective of Interaction Between Manager and Employee)", $J$. 
Bisnis, 2017.

[15] Dasman, Lanin, "Citizen Satisfaction with Local Government Service: The Influence of Manager Role on Public Service Improvement in Local Government", J. Tingkap, vol 10, no 2, 2014, [Online]. Available at: http://ejournal.unp.ac.id/index.php/tingkap/issue/view/522.

[16] Dasman Lanin, "The Effect of Bureaucracy-Internal Politics Towards Citizen Satisfaction.,Nov.010”, J. Adm. Sci. Organ. Bisnis\&Birokrasi, vol 173, 2010, [Online]. Available at: https://scholar.google.co.id/citations?user=KJbLPZEAAAAJ\&hl=en\#d=gs_md_citad $\& \mathrm{p}=\& \mathrm{u}=\%$ FCitations $\% 3$ Fview_0p\%3Dview_citation $\% 25 \mathrm{hl} \% 3 \mathrm{Den} \% 26 \mathrm{user} \% 3 \mathrm{DKJb}$ LPZEAAAAJ\%26citation_for_view\%3DKJbLPZEAAAAJ\%3AY0pCki6q_DkC26tzo m\%3D-420.

[17] A. Dasman, Lanin, and M, Fackri, "Conceptualization of Public Service Model on City Government, International Integration for Regional Public Management (ICPM 2014)”, in ICPM, 2014, bll 52-57.

[18] L. Azizah, Bila, Dasman, “The Employee's Professionalism to Realize Public Service Satisfaction”, Asian Soc. Sci. Humanit. Res. Journals, vol 2, no 2, 2020, [Online]. Available https://www.researchgate.net/profile/Bambang_Irawan13/publication/322790858_The _Mechanism of_Public_Complaint_Management_in_Samarinda_Samsat_Office/links/5a7038400f7 e9ba2e1c9618e/The-Mechanism-of-Public-Complaint-Management-in-SamarindaSamsat-Office.pdf\#.

[19] S. Aprileni, D. Lanin, en Syamsir, "Effect of Employee Professionalism and Organization Equity on Patient Satisfaction in Regional General Hospital Padang, Panjang City", 2020, vol 125, no Icpapg 2019, bll 361-369, doi: 10.2991/aebmr.k.200305.220.

[20] Dasman Lanin, "The reinforcement of Foreigner Satisfaction Concept in Immigration Service in Indonesia.”, J. Ilmu Pemerintah., vol 8, no 2, bll 201-227, 2017, [Online]. Available at: http://journal.umy.ac.id/index.php/jsp/erticle/view/3167.

[21] Y. Rahma, D. Lanin, en A. Khaidir, "Implementation of presidential regulation no. 76 of 2013 on public service complaint management by the provincial government of West Sumatra", 2018, doi: 10.29210/2018189.

[22] D. Lanin en Syamsir, "Model Pelayanan Pemerrintah Daerah yang Memuaskan Pelanggan Internal dan Eksternal Berbasis Total Quality Management; di RSUD Padang Panjang", Padang, 2017.

[23] Dasman Lanin, "The reinforcement of Foreigner Satisfaction Concept in Immigration Service in Indonesia.”, J. Stud. Pemerintah., vol 8, no 2, bll 201-227, 2018, [Online]. Available at: http://journal.umy.ac.id/index.php/jsp/erticle/view/3167.

[24] D. Lanin, "The Analysis of Foreigner Satisfaction and Service Quality of Immigration Office Padang", in Conference International Conference on Ethics in Governance (ICONEG), 2017, bll 423-426, [Online]. Available at: http://scholar.google.co.id/citations?user=KJbLPZEAAAAJ\&hl=en\#gs_md_cita\&p= $\& \mathrm{u}=\% 2$ Fcitations\%3Fview_op\%3Dview_citation\%26hl\%3Den\%26user\%3DKJbLPZ EAAAAJ\%26citation_for_view\%3DKJbLPZEAAAAJ\%3AeQOLeE2rZwMC\%26tzo $\mathrm{m} \% 3 \mathrm{D}-420$. 